\title{
Pengembangan Buku Pedoman Praktikum Berbasis Keterampilan Proses Dasar Sains Kelas IV Sekolah Dasar
}

\author{
Eva Novita ${ }^{1}$ \\ ${ }^{1}$ Pendidikan Guru Sekolah Dasar, Universitas Jambi, Indonesia
}

\begin{tabular}{l}
\hline Article Info \\
\hline Article history: \\
Received Des 22, 2019 \\
Revised Des 28, 2019 \\
Accepted Jan 1, 2020 \\
\hline
\end{tabular}

\section{Keywords:}

Buku Pedoman Praktikum

Keterampilan Proses Dasar

Sains

Sekolah Dasar

\begin{abstract}
ABSTRAK
Tujuan Penelitian: Untuk mengetahui prosedur pengembangan dan kelayakan buku pedoman praktikum berbasis keterampilan proses dasar sains kelas IV Sekolah Dasar.
\end{abstract}

Metodologi: Model pengembangan yang digunakan dalam penelitian ini yaitu model pengembangan 4-D (Define, Design, Develop, dan Disseminate). Penelitian ini dilakukan di SD Negeri 45/I Sridadi. Data penelitian diperoleh dari validasi materi dan validasi media. Selain itu, data juga diperoleh dari angket respon guru dan respon siswa.

Temuan utama: Hasil penelitian menunjukkan bahwa uji kevalidan materi termasuk kategori valid, dengan nilai rata-rata 4,42. Hasil validasi media termasuk kategori sangat valid, dengan nilai rata-rata 4,58. Tingkat kepraktisan dari angket respon guru termasuk kategori sangat praktis dengan nilai 4,66. Selanjutnya dari angket respon siswa memperoleh nilai rata-rata 4,67 dengan kategori sangat praktis. Berdasarkan hasil penelitian dapat disimpulkan bahwa buku pedoman praktikum berbasis keterampilan proses dasar sains kelas IV Sekolah Dasar berada pada kategori valid dan praktis

Keterbaruan penelitian: Keterbaharuan dari penelitian ini ialah belum adanya penelitian yang mengkaji suatu permasalahan pendidikan berdasarkan aspek kerja keras siswa di SMP 17 Kota Jambi.

This is an open access article under the $\underline{C C B Y-N C}$ license

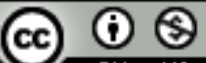

\section{Corresponding Author:}

Eva Novita,

Pendidikan Guru Sekolah Dasar, Universitas Jambi, Jambi, Indonesia

Jl. Teratai, Muara Bulian, Kabupaten Batanghari

Email: $\underline{\text { novitae611@gmail.com }}$

\section{PENDAHULUAN}

Praktikum merupakan kegiatan yang berpusat pada siswa. Suryaningsih (2017: 52) menyatakan bahwa "Pembelajaran berbasis praktikum adalah penyajian pembelajaran dimana siswa membuktikan dan mengalami sendiri sesuatu yang ia pelajari, dengan melakukan percobaan" [1]. Menurut Hamidah, dkk (2014: 50) "Praktikum adalah strategi melalui pemberian pengalaman langsung kepada siswa" [2]. Hal ini berarti dalam kegiatan praktikum siswa mendapat kesempatan untuk mengalami, menemukan, dan membuktikan sendiri konsep yang mereka pelajari. Weatherholt, (2018:3), The practicum is one of the required experiential learning experiences designed to allow students to gain actual experiences in the Exercise Science field under the direct supervision [3]. Dalam pelaksanaan praktikum dibutuhkan salah satu perangkat praktikum yang sangat penting yaitu pedoman praktikum. Pedoman praktikum berisi petunjuk 
pratikum sebagai panduan persiapan, pelaksanaan, dan pelaporan praktikum, sehingga pelaksanaan praktikum lebuh terarah, terencana, dan sistematis.

Berdasarkan observasi yang di lakukan di kelas IV SDN 45/I Sridadi, ditemukan bahwa tidak tersedia pedoman praktikum secara khusus dalam pembelajaran. Pedoman praktikum yang digunakan adalah buku siswa dan LKS (Lembar Kerja Siswa) yang berisi gabungan untuk materi ajar dan kegiatan praktikum. Selain buku siswa dan LKS, terdapat pedoman praktikum yang disampaikan oleh guru yang didapat melalui internet. Pedoman praktikum tersebut tidak semuanya sesuai dengan kemampuan atau kompetensi siswa sekolah dasar. Menurut Niken (2017) "Jika siswa tidak memiliki pedoman praktikum, maka siswa akan mengalami kesulitan dalam melakukan praktikum, sehingga mempengaruhi motivasi siswa terhadap praktikum yang akan dilakukan" [4]. Berdasarkan hasil observasi tersebut, maka dibutuhkan pedoman praktikum secara khusus dan sesuai dengan karakteristik siswa Sekolah Dasar. Hal ini bertujuan agar kegiatan praktikum lebih terarah, terencana, dan sistematis, sehingga akan berpengaruh pada kualitas, motivasi, dan hasil belajar siswa. The main activity in science studies is an experiment that requires a component of teaching, learning, and science practice involving the acquisition of science process skills [5, 6]. Salah satu pedoman yang dapat membantu pelaksanaan praktikum yaitu buku pedoman praktikum. Buku pedoman praktikum adalah buku untuk membantu pelaksanaan praktikum yang memuat petunjuk mengenai tata cara persiapan, pelaksanaan, dan pelaporan praktikum. Selain itu, buku pedoman praktikum dapat memberikan informasi, menjadi penunjang pembelajaran, dan sebagai pegangan siswa dalam melakukan praktikum. Hal ini sesuai dengan penelitian Syamsu (2017: 14) menyatakan bahwa dengan adanya pedoman praktikum, "Pedoman praktikum memuat komponen tujuan, manfaat, dan proses. Siswa mendapat gambaran dan melakukan persiapan mengenai praktikum dengan membaca pedoman praktikum terlebih dulu" [7].

Menurut Semiawan (2008) alasan keterampilan proses dasar sains sangat penting yaitu "Siswa akan mudah memahami konsep yang abstrak jika disertai contoh nyata, menanamkan sifat ilmiah dan melatih melakukan penyelidikan ilmiah, menjadi wahana untuk pengembangan konsep, sikap dan nilai" [8]. Kustijono (2018), "When students carry out the practicum, they can share the task and role in completing the investigation, and each student can play a role according to his task of synergizing and integrating the results into group success" [9]. Diharapkan praktikum berbasis keterampilan proses dasar sains dapat meningkatkan motivasi, aktivitas, dan hasil belajar siswa. Hal ini sesuai dengan penelitian Arsih, dkk (2017) menyatakan bahwa "Materi yang diajarkan akan lebih mudah diingat dan dihayati dengan melatih keterampilan proses sains siswa". Dengan demikian perlu dilakukan Pengembangan Buku Pedoman Praktikum Berbasis Keterampilan Proses Dasar Sains Kelas IV Sekolah Dasar” [10].

\section{METODE PENELITIAN}

Metode penelitian yang digunakan adalah metode penelitian dan pengembangan atau Research and Development (R\&D). Metode Research and Development (R\&D) menurut Sugiyono (2016) merupakan metode penelitian yang digunakan untuk tujuan menghasilkan produk tertentu, serta untuk menguji keefektifan produk tersebut [11]. Produk yang dikembangkan oleh peneliti yaitu buku pedoman praktikum berbasis keterampilan proses dasar sains kelas IV sekolah dasar. Model pengembangan yang digunakan yaitu model pengembangan 4- $D$ yang terdiri dari 4 tahap pengembangan yaitu, define (pendefinisian), design (perancangan), develop (pengembangan), dan disseminate (penyebaran). Penulis memilih model pengembangan 4- $D$ karena model ini sesuai dengan pengembangan yang dilakukan, serta bersifat menganalisis kebutuhan, sederhana, dan mudah dipelajari.

Jenis data yang diambil dalam penelitian ini dikelompokkan menjadi dua bagian, yaitu data kualitatif dan kuantitatif. Data kualitatif diperoleh dari tahap kritik, saran, dan tanggapan dari validator materi, validator media. Sedangkan data kuantitatif diperoleh dari angket respon guru dan siswa. Angket respon guru digunakan untuk melihat kepraktisan buku pedoman praktikum. Angket respon guru menggunakan 5 alternatif pernyataan yaitu Sangat Setuuju (SS), Setuju (S), Cukup Setuju (CS), Kurang Setuuju (KS), Tidak Setuju (TS) dan angket respon siswa dipakai untuk melihat kepraktisan buku pedoman praktikum dan mengetahui respon siswa sebagai pengguna buku pedoman praktikum dalam proses pembelajaran. Angket respon siswa menggunakan 5 alternatif pernyataan yaitu Sangat Setuju (SS), Setuju (S), Setuju (S), Cukup Setuju (CS), dan Tidak Setuju (TS).

Subjek uji coba pada penelitian ini yaitu siswa kelas IV SD Negeri 45/I Sridadi. Dalam hal ini akan dilakukan uji coba kelompok kecil dan uji coba kelompok besar. Uji coba kelompok kecil dipilih 6 orang siswa. Pengambilan subjek dilakukan secara acak, yaitu dengan pertimbangan tertentu, dimana setiap siswa memiliki kemampuan yang berbeda. Kategori yang dipilih, yakni 2 orang siswa yang mempunyai prestasi tinggi, 2 orang siswa mempunyai prestasi sedang, dan 2 orang siswa yang mempunyai prestasi rendah. Uji kelompok kecil ini bertujuan untuk melihat keterbacaan produk atau keterpakaian produk yang dibuat. Subjek uji coba kelompok besar yaitu seluruh siswa kelas IV SD Negeri 45/I Sridadi. Uji coba kelompok 
besar dilakukan untuk mengetahui kepraktisan dari buku pedoman praktikum berbasis keterampilan proses dasar sains pada pembelajaran IPA melalui angket respon siswa.

\section{HASIL DAN PEMBAHASAN}

Hasil penelitian dan pengembangan ini berupa buku pedoman praktikum berbasis keterampilan proses dasar sains untuk kelas IV Sekolah Dasar menggunakan model 4-D. Langkah-langkah dalam penelitian pengembangan model 4-D terdiri atas 4 tahap:

\subsection{Tahap Pendefinisian (Define)}

Pendefinisian (define) adalah tahap pertama yang dilakukan penulis dalam proses penelitian dan pengembangan model 4-D. Pada tahap ini terdiri dari beberapa analisis. Tujuan analisis adalah untuk menetapkan arah dasar yang dibutukan dalam pengembangan buku pedoman praktikum. Tahap pendefinisan terdiri atas analisis karakteristik siswa, analisis konsep, dan perumusan tujuan pembelajaran.

\subsection{Tahap Perancangan (Design)}

Tahap perancangan bertujuan mendesain produk yang akan dikembangkan. Pada tahap ini masih berbentuk sketsa produk yang akan dibuat. Berikut desain produk yang dihasilkan:

\subsubsection{Cover}

Dirancang sesuai judul praktikum dan gambar-gambar yang sesuai materi atau kegiatan praktikum yang ada dalam isi buku dengan desain cover menggunakan warna biru

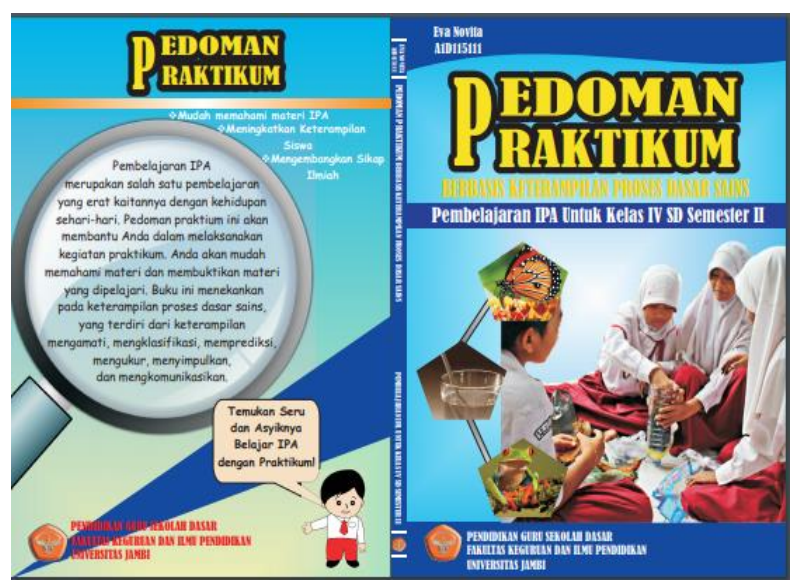

Gambar 1. Cover Buku

\subsubsection{Isi pedoman praktikum.}

Uraian isi buku dikembangkan dalam bentuk teks. Uraian isi buku memuat kegiatan paktikum dan soal latihan. Setiap awal pelajaran terdapat KD yang menginformasikan materi yang akan dipraktikumkan, serta terdapat gambar yang mengilustasikan materi. 


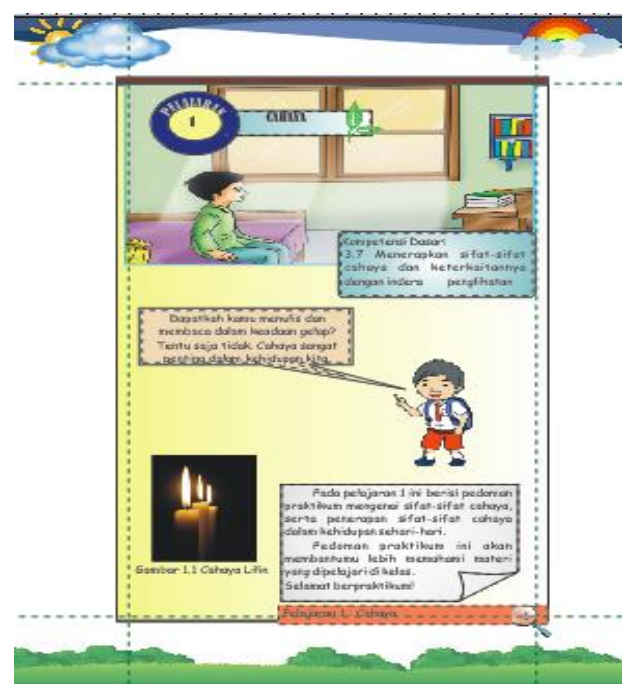

Gambar 2. Isi Buku

\subsection{Tahap Pengembangan (Develop)}

\subsubsection{Validasi Materi}

Validasi materi dilaksanakan selama tiga tahap. Validator materi yaitu Bapak Hendra Budiono, S.Pd., M.Pd.Validator ahli materi mengevaluasi materi pembelajaran yang terdapat dalam buku pedoman praktikum. Adapun penilaian validasi materi yaitu sebagai berikut:

Tabel 1. Validasi Materi

\begin{tabular}{|c|c|c|c|c|}
\hline \multirow{2}{*}{ No } & \multirow{2}{*}{ Deskriptor } & \multicolumn{3}{|c|}{ Penilaian Validasi } \\
\hline & & Tahap I & Tahap II & Tahap III \\
\hline 1 & $\begin{array}{l}\text { Materi yang disajikan mencakup materi ang terkandung } \\
\text { dalam KD }\end{array}$ & 3 & 4 & 4 \\
\hline 2 & $\begin{array}{l}\text { Materi yang disajikan mencerminkan jabaran yang } \\
\text { mendukung pencapaian KD }\end{array}$ & 4 & 4 & 4 \\
\hline 3 & $\begin{array}{l}\text { Materi yang disajikan sesuai dengan tingkat pendidikan di } \\
\text { SD }\end{array}$ & 4 & 4 & 4 \\
\hline 4 & Konsep dirumuskan dengan tepat sesuai KI dan KD & 2 & 4 & 4 \\
\hline 5 & $\begin{array}{l}\text { Materi yang disajikan menarik dan dapat menimbulkan rasa } \\
\text { ingin tahu }\end{array}$ & 2 & 5 & 5 \\
\hline 6 & $\begin{array}{l}\text { Materi yang disajikan mendorong siswa untuk mencari } \\
\text { informasi lebih lanjut }\end{array}$ & 5 & 5 & 5 \\
\hline 7 & Penyajian materi bersifat interaktif dan partisipatif & 2 & 4 & 4 \\
\hline 8 & $\begin{array}{l}\text { Pesan atau informasi disampaikan dengan bahasa yang } \\
\text { menarik dan jelas }\end{array}$ & 2 & 2 & 4 \\
\hline 9 & $\begin{array}{l}\text { Bahasa yang digunakan sesuai dengan tingkat } \\
\text { perkembangan kognitif siswa }\end{array}$ & 4 & 4 & 4 \\
\hline 10 & $\begin{array}{l}\text { Bahasa yang digunakan sesuai dengan tingkat } \\
\text { perkembangan emosional peserta didik }\end{array}$ & 4 & 4 & 4 \\
\hline & Jumlah & 32 & 40 & 42 \\
\hline
\end{tabular}

Berdasarkan tabel hasil validasi ahli materi tahap III diperoleh hasil skor rerata yaitu:

$$
R=\frac{42}{1.10}=4,2
$$

Hasil skor rerata validasi tahap III menunjukkan bahwa buku pedoman praktikum valid. Serta validator memberikan kesimpulan produk layak untuk diuji cobakan tanpa revisi.

\subsubsection{Validasi Media}

Validasi media oleh dosen validator yaitu Bapak Agung Rimba Kurniawan, S.Pd., M.Pd. Skor Penilaian oleh validasi ahli media terhadap 12 deskriptor (1) Ketepatan ukuran buku yang digunakan, (2) Ketepatan desain kulit buku depan dan belakang (satu kesatuan), (3) Ketepatan pemilihan penggunaan warna 
kulit buku, (4) Penggunaan warna huruf kulit buku dapat memperjelas isi buku, (5) Penggunaan huruf pada kulit buku menarik dan mudah dibaca, (6) Ukuran huruf yang digunakan pada kulit buku proporsional, (7) Kulit buku tidak terlalu banyak menggunakan kombinasi jenis huruf, (8) Bentuk, warna dan ukuran objek ditampilkan sesuai realita, (9) Penempatan unsur tata letak (judul, subjudul, dll) konsisten, (10) Isi buku tidak menggunakan terlalu banyak jenis huruf, (11) Penggunaan variasi huruf (bold, italic, dan all capital) tidak berlebihan, (12) Keterbacaan huruf dalam isi bukua, diperoleh skor sebesar 55. Berdasarkan penilaian hasil validasi media diperoleh nilai rerata sebagai berikut:

$$
R=\frac{55}{1.12}=4,58
$$

Hasil dari rerata validasi ahli media menunjukkan bahwa buku pedoman praktikum memperoleh kategori sangat valid. Validator memberikan kesimpulan bahwa media sudah valid dan layak diuji cobakan

\subsubsection{Uji Coba Produk}

Berdasarkan uji coba kelompok kecil, penulis mendapatkan respon postif dari siswa. Namun terdapat komentar dari beberapa siswa. Adapun catatan lapangan uji coba kelompok kecil yaitu ketidaksesuaian penulisan kegiatan pada data hasil pengamatan dengan prosedur kerja, serta memperbesar ukuran judul pada awal pelajaran. Catatan yang ditemukan oleh penulis kemudian diperbaiki sesuai dengan komentar siswa. Setelah dilakukan perbaikan produk dari catatan uji coba kelompok kecil, kemudian penulis melakukan uji coba kelompok besar. Uji coba kelompok besar digunakan untuk melihat kepraktisan buku pedoman praktikum berbasis keterampilan proses dasar sains melalui angket respon siswa. Berdasarkan uji coba kelompok besar maka didapatkan nilai rata-rata respon masing-masing siswa secara keseluruhan yaitu 130,66, kemudian dilakukan perhitungan sebagai berikut:

$$
R_{\text {total }}=\frac{130,66}{28}=4,67
$$

Berdasarkan hasil tersebut, maka tingkat kepraktisan buku pedoman praktikum berbasis keterampilan proses dasar sains termasuk ke dalam kategori sangat praktis.

Adapun respon guru terhadap buku pedoman praktikum dilakukan setelah penggunaan buku pedoman praktikum. Guru kelas IV yang menjadi responden pengisian angket adalah Siti Mahariyani, S.Pd. SD. Adapun angket respon guru dapat dilihat pada Tabel 2 berikut:

\begin{tabular}{|c|c|c|}
\hline No & Deskriptor & Skor \\
\hline 1 & Buku pedoman praktikum jelas penyajiannya & 5 \\
\hline 2 & Buku pedoman praktikum rapi dalam susunan dan penataannya & 4 \\
\hline 3 & Penyajian buku bersih dan proporsional & 3 \\
\hline 4 & Buku pedoman praktikum dapat menarik minat siswa untuk belajar & 5 \\
\hline 5 & Buku pedoman praktikum sesuai dengan karakteristik siswa & 5 \\
\hline 6 & Buku pedoman praktikum sesuai dengan topik yang diajarkan & 5 \\
\hline 7 & Buku pedoman praktikum dapat digunakan berulang-ulang & 5 \\
\hline 8 & Buku pedoman praktikum mudah digunakan & 5 \\
\hline 9 & Buku pedoman praktikum mudah dibawa kemana-mana dan mudah dipindahkan & 5 \\
\hline 10 & Buku pedoman praktikum memiliki kualitas yang baik & 4 \\
\hline 11 & Ukuran buku pedoman praktikum sesuai dengan kebutuhan siswa & 5 \\
\hline \multirow[t]{3}{*}{12} & Mudah dibawa dan disimpan & 5 \\
\hline & Jumlah & 56 \\
\hline & Rumus Rerata $\quad R=\frac{\sum_{j=1}^{n} V i j}{n m}$ & 4,66 \\
\hline
\end{tabular}

Tabel 2. Penilaian Angket Respon Guru

Berdasarkan tabel diatas, dapat diketahui respon guru terhadap buku pedoman pratikum termasuk dalam kategori sangat praktis. Dalam hal ini telah dilakukan penilaian kepraktisan oleh guru dan siswa, buku pedoman praktikum yang dikembangkan telah layak digunakan dalam pembelajaran.

\subsection{Tahap Penyebaran (Disseminate)}

Tahap penyebaran adalah tahap terakhir dalam model pengembangan 4-D. Pada tahap ini, buku pedoman praktikum dilakukan penyebaran dengan memperluas penggunaan buku di sekolah lain, yaitu pada

JEE. Vol. 1, No. 1, Januari 2020: 34 - 41 
kelas IV A SD Negeri 13/I Muara Bulian. Untuk penggunaan buku pada tahap penyebaran ini dijelaskan bahwa buku pedoman praktikum yaitu untuk pembelajaran IPA kelas IV SD, sehingga buku pedoman praktikum dapat digunakan secara umum oleh kelas IV lainnya. Dalam proses penyebaran ini, guru terlebih dahulu menjelaskan penggunaan buku. Kemudian, dilakukan pembelajaran dengan menggunakan buku pedoman praktikum berbasis keterampilan proses dasar sains. Secara umum siswa memberi respon positif terhadap produk. Beberapa komentar dari siswa yaitu "bukunya bagus", "tampilan buku menarik", "bukunya menarik". Selain itu, guru memberi pendapat bahwa buku yang dikembangkan sangat membantu dan mengarahkan guru serta siswa dalam kegiatan praktikum mulai dari perencanaan, pelaksanaan, dan pelaporan. Guru berpendapat bahwasanya buku pedoman praktikum menjelaskan kegiatan praktikum secara rinci, sedangkan di buku siswa yang biasanya digunakan pedoman praktikumnya kurang jelas. Di buku siswa tersebut, siswa hanya melakukan praktikum, setelah itu siswa melakukan analisis tanpa menggunakan pedoman, sehingga banyak siswa merassa bingung. Selain itu, guru pun menyatakan bahwa siswa akan lebih memahami materi jika diberikan pembelajaran yang langsung melibatkan siswa.

Pembelajaran IPA adalah pembelajaran yang mengajarkan tentang produk, proses, dan sikap ilmiah. Ketiga hal tersebut tidak dapat dicapai hanya dengan penjelasan teori dan hafalan. Menurut Susanto (2013) "Pembelajaran IPA di Sekolah Dasar bukan hanya hafalan terhdap materi IPA, tetpi dilakukan penyelidikan sederhana atau praktikum" [12]. Artinya, dalam pembelajaran IPA yang mencakup produk, proses, dan sikap ilmiah dibutuhkan praktikum dalam pembelajaran IPA. Pada pelaksanaan praktikum dibutuhkan salah satu perangkat praktikum yaitu pedoman praktikum.

Pedoman praktikum belum tersedia secara khusus di Sekolah Dasar. Pedoman praktikum yang digunakan yaitu diambil dari buku siswa dan LKS. Berdasarkan analisis buku siswa dan analisis LKS, diketahui bahwa terdapat permasalahan pada pedoman praktikum, seperti terdapat pedoman praktikum yang tidak sesuai dengan kompetensi siswa sekolah dasar, beberapa pedoman prakikum tidak mencantumkan judul dan tujuan praktikum, terdapat pedoman praktikum yang tidak disertai langkah-langkah kerja dan lembar hasil pengamatan. Pada analisis LKS, juga ditemukan permasalahan yaitu pedoman praktikum yang ada hanya memuat alat, bahan, dan langkah kerja. Selain itu, kertas yang digunakan buram dan berwarna hitam putih sehingga kurang menarik perhatian siswa. Berdasarkan analisis kebutuhan, maka dibutuhkan pedoman praktikum sesuai dengan kompetensi siswa sekolah dasar, serta memuat keterampilan proses dasar sains. Menurut Arsih, dkk (2017) "Materi yang diajarkan akan lebih mudah diingat, dan dihayati dengan melatih ketermpilan proses sains siswa" [10]. Melalui buku pedoman praktikum berbasis keterampilan proses dasar sains, pelaksanaan praktikum dapat menjadi lebih terarah, terencana, dan sistematis.

Penelitian ini merupakan jenis penelitian $R \& D$ dengan menggunakan model 4- $D$ yaitu Define (Pendefinisian), Design (Perancangan), Develop (Pengembangan), dan Disseminate (Penyebaran). Model 4$D$ dipilih karena mudah dipelajari, dan urutan kegiatannya sistematis untuk memecahkan masalah dalam pembelajaran. Sejalan dengan pendapat Smith dan Ilery (2013) yang menyatakan bahwa "Model 4-D berisi kegiatan yang disusun secara berurutan, dan sistematis untuk memecahkan masalah dalam pembelajaran yang disesuaikan dengan karakteristik siswa dan analisis kebutuhan" [13]. Pada tahap define yang dilakukan yaitu analisis karakteristik siswa. Analisis karakeristik siswa, analisis konsep, dan perumusan tujuan pembelajaran. Analisis karakteristik siswa dilakukan agar produk ang dikembangkan sesuai dengan karakteristik siswa. Menurut Alfin (2015) "Kegiatan menganalisis karakteristik siswa adalah cara yang digunakan untuk mendapatkan pemahaman mengenai minat, dan kebutuhan siswa" [14]. Setelah itu, dilakukan analisis konsep. Analisis konsep dilakukan untuk mengetahui materi yang akan dipraktikumkan dan dimuat dalam buku pedoman praktikum.

Pada tahap design dilakukan pemilihan format buku dan membuat desain awal buku. Setelah pemilihan format buku dilakukan, selanjutnya dibuatlah desain awal media atau buku yang dikembangkan. Tahap selanjutnya yaitu develop. Di tahap ini dilakukan validasi buku dan uji coba produk, agar didapatkan buku pedoman praktikum yang layak digunakan. Suatu produk pengembangan dikatakan layak digunakan apabila telah memenuhi kriteria valid, praktis, dan efektif. Namun dalam penelitian ini kelayakan produk hanya valid dan praktis. Untuk mendapatkan buku pedoman praktikum yang valid, maka dilakukan validasi terhadap buku pedoman praktikum. Kevalidan buku pedoman praktikum didapatkan dari hasil validasi media dan validasi materi. Widoyoko (2017) menyatakan bahwa "Validitas adalah ketepatan alat ukur. Instrumen yang sah mempunyai validitas yang tinggi, sedangkan instrumen yang kurang valid memiliki validitas rendah" [15]. Validator memiliki keahlian di bidang pendidikan dengan tingat pendidikan Strata Dua (S2) dan memiliki pengalaman dalam bidang penelitian.

Data yang diperoleh dari validasi tahap III mendapatkan rata-rata 4,2 dengan kategori valid. Selanjutnya validasi media mendapatkan nilai rata-rata 4,58 dengan kategori sangat valid dan diberikan beberapa komentar oleh validator. Buku pedoman praktikum yang telah dinyatakan valid, kemudian dilakukan uji coba produk. Uji coba produk dilakukan untuk mendapatkan data kepraktisan produk. Kepraktisan dapat ditinjau dari pertimbangan guru mengenai media, apakah media tersebut mudah dan dapat 
digunakn oleh guru maupun siswa. Untuk tingkat kepraktisan diperoleh dari angket respon siswa dan guru. Tingkat kepraktisan buku pedoman praktikum memperoleh kategori sangat praktis dari angket respon guru dengan rata-rata 4,66 dan rata-rata skor siswa yaitu 4,67.

Tahap penyebaran dilakukan setelah buku pedoman praktikum berbasis keterampilan proses dasar sains dinyatakan valid dan praktis. Tahap penyebaran buku ini digunakan di sekolah lain. Sekolah menjadi tempat penyebaran yaitu SD I3/I Muara Bulian. Hal ini bertujuan untuk mempromosikan buku pedoman praktikum dan mengenalkan buku pedoman praktikum. Selanjutnya, diharapkan buku pedoman praktikum berbasis keterampilan proses dasar sains dapat dikembangkan lagi untuk lebih banyak kompetensi IPA di Sekolah Dasar.

\section{KESIMPULAN}

Berdasarkan penelitian dan pengembangan buku pedoman praktikum berbasisi keterampilan proses dasar sains kelas IV Sekolah Dasar yang telah dilakukan, dapat disimpulkan bahwa: Prosedur pengembangan buku pedoman praktikum berbasis keterampilan proses dasar sains mengacu pada model 4-D dengan tahapan define (Pendefinisian), design (perancangan), develop (pengembangan), dan disseminate (penyebaran). Tingkat kevalidan materi diperoleh dari validator materi yaitu 4,42 dengan kategori valid. Sedangkan validator kevalidan media yang diperoleh dari validator media yaitu 4,58 dengan kategori sangat valid. Tingkat kepraktisan buku pedoman praktikum berbasis keterampilan proses dasar sains diperoleh dari angket respon guru dan respon siswa. Respon guru mendapat skor 4,66 dengan kategori sangat praktis, dan respon siswa mendapat skor 4,67 dengan kategori sangat praktis.

\section{UCAPAN TERIMA KASIH}

Peneliti mengucapkan terima kasih kepada kepala sekolah dan siswa-siswi SMPN 17 Kota Jambi yang telah membantu dalam mensukseskan penelitian ini.

\section{REFERENSI}

[1] Suryaningsih, Yeni "Pembelajaran Berbasis Praktikum sebagai Sarana Siswa untuk Berlatih Menerapkan Keterampilan Proses Sains dalam Materi Biologi. Jurnal Bio Education. Vol 2(2),pp. 2541-2280. 2017

[2] Hamidah, A., Novita, S. E., \& Retni, S. B. "Persepsi Siswa Tentang Kegiatan Praktikum Biologi di Laboratorium SMA Negeri Se-Kota Jambi”. Jurnal Sainmatika. Vol 8(1), pp. 1979-0910. 2014

[3] Weatherholt. A. (2018). Exercise Science Program: Practicum Handbook. University of Southern Indiana: USA

[4] Niken. "Pengembangan Penuntun Praktikum Biologi Bernuansa Keterampilan Proses Sains untuk Siswa Kelas XI Semester Genap”. Jurnal Kesehatan. Vol 8(1), pp. 48-53. 2017

[5] Akani, O. " Levels of Possession of Science Process Skills by Final Year Students of Colleges of Education in South-Eastern States of Nigeria". Journal of Education and Practice, (ISSN 2222-288X), 27(6), pp. 94-102. 2015

[6] Phaeton, M. J., \& Stears, M. "Exploring the Alignment of the Intended and Implemented Curriculum Through Teachers' Interpretation: A Case Study of A-Level Biology Practical Work". EURASIA Journal of Mathematics Science and Technology Education, (ISSN: 1305-8223), 13(3), pp. 723-740. 2017 DOI 10.12973/eurasia.2017.00640a.

[7] Syamsu, D. F. "Pengembangan Penuntun Praktikum IPA berbasis Inkuiri Terbimbing untuk Siswa SMP Siswa Kelas VII Semester Genap”. Jurnal Bionatural. Vol 4(2), pp. 2355-3790. 2017

[8] Semiawan, Conny R. "Belajar dan Pembelajaran Prasekolah dan Sekolah Dasar". 2008 Jakarta: Indeks.

[9] Kustijono, R. " The Effect of Scientific Attitudes Toward Science Process Skills in Basic Physics Practicum By Using Peer Model”. International Journal of GEOMATE 15(50). Pp. 82-87. 2018

[10] Arsih, F., Fitri, R., \& Reslas, Y. "Validitas Panduan Praktikum Fisiologi Hewan Berbasis Keterampilan Proses Sains untuk Mahasiswa Jurusan Biologi Universitas Negeri Padang” . Bioeducation Journal. Vol 1(2), pp. 2354-8363. 2017

[11] Sugiyono. "Metode Penelitian Pendidikan Pendekatan kuantitatif, Kualitatif, dan R\&D. Bandung: Alfabeta. 2016

[12] Susanto, Ahmad. “Teori Belajar dan Pembelajaran di Sekolah Dasar”. Jakarta: Kencana Prenada Media Group. 2013

JEE. Vol. 1, No. 1, Januari 2020: 34 - 41 
[13] Smith, A \& Ilery, S. I.’Pengembangan Bahan Ajar untuk Meningkatkan Mutu Proses dan Hasil Belajar Kimia pada Siswa SMA”. Jurnal Bimafika. (5), pp. 575-578. 2013

[14] Alfin, J. “Analisis Karakteristik Siswa pada Tingkat Sekolah Dasar”. Surabaya: Fakultas Tarbiyah dan Krguruan UIN Sunan Ampel Surabaya. 2015

[15] Widoyoko. “Teknik Penyusunan Instrumen Penelitian”. Yogyakarta: Pustaka Pelajar. 2015 